\title{
Relation between the low temperature stress and catalase activity in gladiolus somaclones (Gladiolus grandiflorus Hort.)
}

\author{
T. Bettaieb ${ }^{\text {a,* }}$, M. Mahmoud ${ }^{\text {b }}$, J.I. Ruiz de Galarreta ${ }^{\text {c }}$, P. Du Jardin ${ }^{\text {d }}$ \\ ${ }^{a}$ Ecole Supérieure d'Horticulture et d'Elevage, 4042 Chott Mariem, Tunisia \\ ${ }^{\mathrm{b}}$ Ecole Supérieure d'Agriculture du Kef, 7119 Kef, Tunisia \\ ${ }^{\mathrm{c}}$ NEIKER-Basque Institutes for Agricultural Research, P.O. Box 46, 01080 Vitoria, Spain \\ ${ }^{\mathrm{d}}$ Faculté Universitaire des Sciences Agronomiques de Gembloux, Belgium
}

Received 3 April 2006; received in revised form 2 November 2006; accepted 12 January 2007

\begin{abstract}
In order to evaluate low temperature tolerance of five variable somaclones as well as the cv. Peter Pears of gladiolus (Gladiolus grandiflorus Hort.) from which they were originated, catalase (CAT) activity and hydrogen peroxide $\left(\mathrm{H}_{2} \mathrm{O}_{2}\right)$ level were measured. Before carrying out the analyses, vitroplants of these clones were exposed, during 21 days, to $8{ }^{\circ} \mathrm{C}$ temperature. In response to the stress generated by this low temperature, catalase (CAT) activity revealed on native gel and quantified by spectrophotometry, showed variable levels, being all of them higher compared to cultivar control. For these clones, strong CAT activities were always accompanied by low $\mathrm{H}_{2} \mathrm{O}_{2}$ levels. Thus, at low temperatures the antioxidants system of adapted clones is more active compared to control.
\end{abstract}

(C) 2007 Elsevier B.V. All rights reserved.

Keywords: Low temperature tolerance; Catalase activity; Hydrogen peroxide

\section{Introduction}

Biotic and abiotic stresses such as drought, salinity, diseases and thermal stresses accelerate the production of active oxygen species (AOS) which then exceeds the capacity of the cells antioxidant system (Foyer et al., 1994; Bowler and Fluhr, 2000). Cells have an enzymatic and non-enzymatic antioxidant system to neutralize these free radicals. In higher plants three major enzymes are implicated in the AOS detoxification: superoxide dismutase (SOD), ascorbate peroxidase (APX) and catalases (Dodet, 1991; Willekens et al., 1995; Scandalios, 2002). In the case of cold sensitive plants, catalases are more implicated than other enzymes (Volk and Feirabend, 1989).

Among AOS, hydrogen peroxide $\left(\mathrm{H}_{2} \mathrm{O}_{2}\right)$ seems to be implicated in various stress situations (Bowler and Fluhr, 2000). In fact, $\mathrm{H}_{2} \mathrm{O}_{2}$ as well as after its transformation into radical $\mathrm{OH}$, is the origin of direct cellular damage. In addition to the main role of CAT in the control of $\mathrm{H}_{2} \mathrm{O}_{2}$ level in plant cells, significant functions in the stress responses are linked to these

\footnotetext{
* Corresponding author. Tel.: +21698206 614 .

E-mail address: tbettaieb@yahoo.fr (T. Bettaieb).
}

enzymes. Wadsworth and Scandalios (1990) indicated that a deficiency in CAT remarkably reduced the germination rate of barley and corn seeds. Willekens et al. (1997) indicated in their work on tobacco lines with partially limited CAT activity, that these enzymes belong to the normal process of the photosynthetic mechanism and are essential for the oxidative stress response. Shikanai et al. (1998) observed an improvement of the tolerance to light stress and drought that over express CAT activity.

Among environment limits, light deficiency and thermal shocks are regarded as the most significant factors that affect CAT activity (Volk and Feirabend, 1989; Willekens et al., 1997; Matsumura et al., 2002; Sairam et al., 2002). In order to establish a possible relation between cold tolerance and certain antioxidant enzymes, CAT activity was analyzed and $\mathrm{H}_{2} \mathrm{O}_{2}$ level was measured for five gladiolus vitrovariants $\left(\mathrm{R}_{1}, \mathrm{Rb}_{1}, \mathrm{Rb}_{2}, \mathrm{Rib}_{1}\right.$, $\mathrm{Rib}_{2}$ ) selected in a previous work (Bettaieb, 2003) for their tolerance to low temperatures and adapted to winter culture.

\section{Materials and methods}

The vitrovariants were regenerated from irradiated callus of 'Peter Pears' with gamma ray (50 Gy). The cultivar 'Peter Pears' was used as control before undertaking analysis, vitroplants were 
placed in 11 bottles containing a culture medium consisting of rock salt and vitamins of Murashige and Skoog (1962) with $30 \mathrm{~g}^{-1}$ of sucrose and $0.5 \mathrm{mg}^{-1}$ of IBA (indole-3-butyric acid). The $\mathrm{pH}$ of culture medium was adjusted to 5.8 and this medium was solidified with agar $\left(6 \mathrm{~g} \mathrm{l}^{-1}\right)$. The bottles remained 21 days at $8{ }^{\circ} \mathrm{C}$ (to induce the thermal stress), with a photoperiod of $11 \mathrm{~h}$ at $36 \mu \mathrm{mol} \mathrm{m} \mathrm{m}^{-2} \mathrm{~s}^{-1}$. Frozen plant tissues were ground to a fine powder in a pestle with liquid nitrogen and mixed with 1 volume of extraction buffer $(50 \mathrm{mM}$ potassium phosphate $\mathrm{pH}$ 7.6, $10 \mathrm{mM}$ sodium metabisulfite, $1 \mathrm{mM}$ ascorbic acid, $1 \mathrm{mM}$ EDTA, 20\% (w/v) sorbitol, 2\% (w/v) polyvinylpolypyrrolidone and centrifuged at $12,000 \times g \times 20 \mathrm{~min}$ at $4{ }^{\circ} \mathrm{C}$. The supernatant was collected and the protein concentration was determined using Bradford's method (1976).

Soluble protein samples were subjected to non-denaturing PAGE $10 \%$ according to Laemmli (1970). Catalase activity was revealed on the gel as follows: the gel was washed three times (15 min each) with water, then incubated for $10 \mathrm{~min}$ in $0.88 \mathrm{mM} \mathrm{H}_{2} \mathrm{O}_{2}$ solution, rinsed again with water, and finally incubated with $1 \%(\mathrm{w} / \mathrm{v})$ of ferric chloride and potassium ferricyanide solution until yellow bands appeared on a green background). CAT activity was measured essentially as described by Clairbone (1985), with some modifications. The assay contained $15 \mathrm{mM} \mathrm{H}_{2} \mathrm{O}_{2}$ in $50 \mathrm{mM}$ phosphate buffer (pH 7.0) and $80 \mu \mathrm{g}$ of protein extract in total volume of $1 \mathrm{ml}$. CAT activity was estimated by a decrease of $\mathrm{H}_{2} \mathrm{O}_{2}$ absorbance at $240 \mathrm{~nm}$ and one unit of CAT was defined as the amount of enzyme dismounting $1 \mu \mathrm{mol}$ of $\mathrm{H}_{2} \mathrm{O}_{2}$ per minute.

The quantification of $\mathrm{H}_{2} \mathrm{O}_{2}$ was determined by chemiluminescence (Warm and Laties, 1982), with modifications (Noel, 2001). One gram of plant tissue was ground in liquid nitrogen, mixed to $250 \mathrm{mg}$ of active charcoal and extraction was with $4 \mathrm{ml}$ of ice cold $5 \%(\mathrm{w} / \mathrm{v})$ trichloracetic acid. The crude extracts were centrifuged for $30 \mathrm{~min}$ at $12,000 \times g$. Two milliliters of supernatant were passed two times through a BioRad column AG1 ${ }^{*} 8$ (poly-prep prefilled chromatography columns), in the dark and cold room $\left(8{ }^{\circ} \mathrm{C}\right) . \mathrm{H}_{2} \mathrm{O}_{2}$ content was measured by adding $50 \mu \mathrm{l}$ of eluate to $50 \mu \mathrm{l}$ of $0.5 \mathrm{mM}$ luminol and $100 \mu \mathrm{l}$ of $0.5 \mathrm{mM}$ ferricyanide $\left(\mathrm{K}_{3} \mathrm{Fe}(\mathrm{CN})_{6}\right)$. The luminol and the ferricyanide were solubilized in $\mathrm{NH}_{4} \mathrm{OH} \mathrm{pH}$ 9.5. Recovery estimates (which consisted of adding a known concentration of $\mathrm{H}_{2} \mathrm{O}_{2}$ to aliquots of the initial extracts that were processed in parallel). Average of $90 \%$ was recovered and used as a correction factor for each sample. The experiment was repeated three times and the average was considered. Trials were carried out according to a completely random block model. Each treatment was randomized on three blocks and each experimental unit related to a treatment in a block consisted of six homogeneous vitroplants. The Duncan test has been conducted to check difference between means at the $1 \%$ level.

\section{Results}

Staining gel showed superiority in the catalase activity at the vitrovariants selected for their cold tolerance as compared to the control. Differences between these genotypes were also observed (Fig. 1).

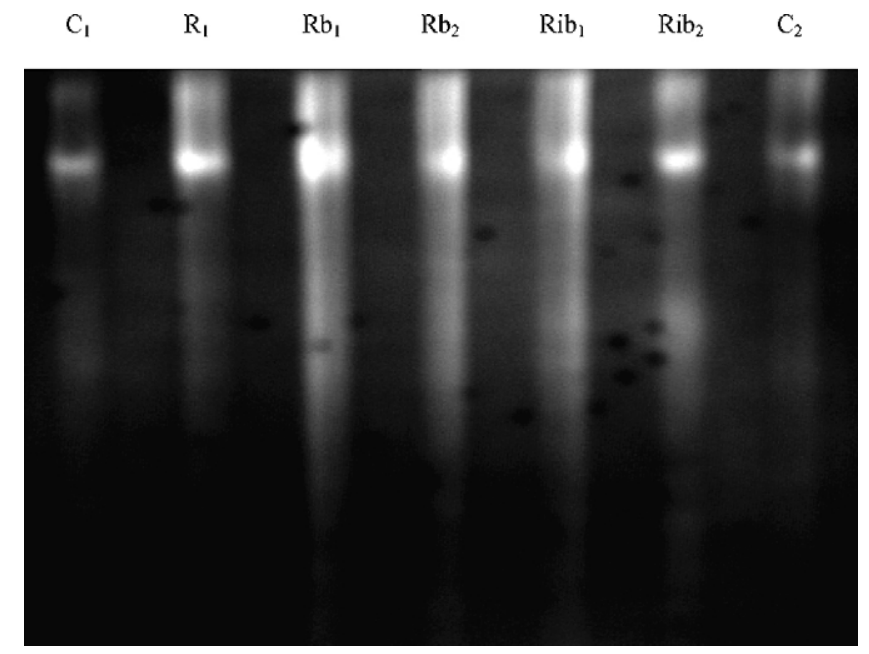

Fig. 1. Zymogram analysis of catalase activity in five clones $\left(R_{1}, R b_{1}, R b_{2}\right.$, $\mathrm{Rib}_{1}$ et $\mathrm{Rib}_{2}$ ) of gladiolus (Gladiolus grandiflorus Hort.) and in two samples of the cv. control Peter Pears $\left(\mathrm{C}_{1}\right.$ and $\left.\mathrm{C}_{2}\right)$ grown at $8{ }^{\circ} \mathrm{C}$.
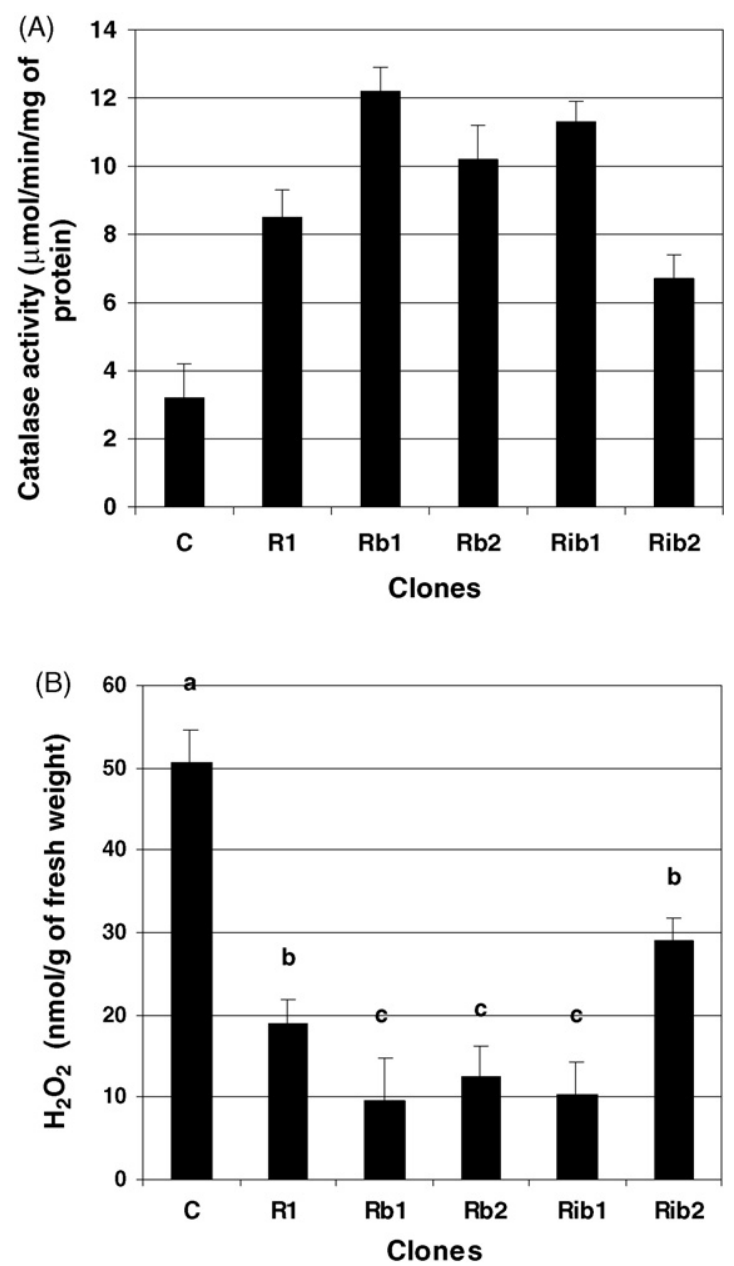

Fig. 2. Catalase activity (A) and hydrogen peroxide content (B) in tissue for five clones $\left(\mathrm{R}_{1}, \mathrm{Rb}_{1}, \mathrm{Rb}_{2}, \mathrm{Rib}_{1}\right.$ et $\left.\mathrm{Rib}_{2}\right)$ of gladiolus (Gladiolus grandiflorus Hort.) and of the control cv. Peter Pears grown at $8{ }^{\circ} \mathrm{C}$. Indicated values represent the averages of the three repetitions. Bars represent the average of their estimated standard deviation. Means with the same letters are not significant at $p=0.01$ probability level of Duncan test. 
The spectrophotometry quantification of total catalase activity gave results comparable to those observed on nondenaturing gel PAGE with a superiority in all selected genotypes compared to the control (Fig. 2A). The statistical analysis showed highly significant differences between the control and genotypes for total CAT activity. Differences were also observed among genotypes with a superiority of $\mathrm{Rb}_{1}, \mathrm{Rb}_{2}$ and $\mathrm{Rib}_{1}$. The $\mathrm{H}_{2} \mathrm{O}_{2}$ content showed highly significant differences between the control and selected genotypes for their tolerance to low temperatures (Fig. 2B). The control had the lowest level of CAT activity and the highest $\mathrm{H}_{2} \mathrm{O}_{2}$ content. The lowest level of $\mathrm{H}_{2} \mathrm{O}_{2}$ was observed in the genotypes $\mathrm{Rb}_{1}$ which shows the highest level of CAT activity. Indeed, a high correlation $\left(r^{2}=0.95\right)$ exists between these two parameters.

\section{Discussion}

The results of our experiments demonstrate that low temperatures induce an accumulation of AOS - who play a role in the photosystem II (PSII) operation (Willekens et al., 1997). The $\mathrm{H}_{2} \mathrm{O}_{2}$ accumulation was observed in the control (cv. Peter Pears) characterized by its sensitivity to cold (Vidalie, 1978). For the selected genotypes, the low level of $\mathrm{H}_{2} \mathrm{O}_{2}$ is explained by the important CAT activity that these genotypes exhibit.

Indeed CAT are the first enzymes which take place in $\mathrm{H}_{2} \mathrm{O}_{2}$ neutralization and thus could avoid cellular damage caused by excessive accumulation of the substrate (Willekens et al., 1994). James et al. (2001) pointed out, in their work on the deficient tobacco plant, the importance of these enzymes under stress conditions and enumerated several roles of $\mathrm{H}_{2} \mathrm{O}_{2}$ in molecular and biochemical plant mechanisms in response to stress conditions (Foyer and Noctor, 2005).

Feirabend et al. (1992) observed a reduction of $28 \%$ of catalase activity and an accumulation of $\mathrm{H}_{2} \mathrm{O}_{2}$ in rice seedlings exposed to $4{ }^{\circ} \mathrm{C}$. After $24 \mathrm{~h}$ of seedlings transfer to $25^{\circ} \mathrm{C}$, these enzyme activity is restored. In addition, Volk and Feirabend (1989) suggested that, among the environmental constraints, thermal shocks are regarded as factors reducing catalase activity more than other enzymes. Puntarol et al. (1988) showed that the catalases are responsible for $\mathrm{H}_{2} \mathrm{O}_{2}$ elimination and that an over activity exhibition of these enzymes is able to induce hydrogen peroxide detoxification and is considered as a strategy for improving tolerance to the stress for plant cells.

\section{Conclusion}

The evaluation of the catalase activity and hydrogen peroxide measured in tissues of various selected vitrovariants for their tolerance to low temperatures showed different activities of somaclones. All somaclonal variants obtained in this work exhibited a catalase activity more significant than that of the control. $\mathrm{Rb}_{1} \mathrm{Rb} 2$ clones and $\mathrm{Rib}_{1}$ have the most significantly catalase activities and consequently the lowest $\mathrm{H}_{2} \mathrm{O}_{2}$ contents. These results allow conclude that in the presence of low temperatures, the antioxidant system of adapted clones is more active compared to control. The difference in activity between vitrovariants was also high- lighted. Considering this behavior, it may be inferred that these clones are becoming tolerant to the low temperature.

\section{References}

Bettaieb, T., 2003. Régénération de vitrovariants de glaïeul (Gladiolus randiflorus Hort.) tolérant les basses temperatures. Ph.D. Institut National agronomique de Tunisie, p. 115.

Bowler, C., Fluhr, R., 2000. The role of calcium and actived oxygen as signals for controlling cross tolerance. Trends Plants Sci. Rev. 5, 241-246.

Bradford, M.M., 1976. A rapid and sensitive method for the quantification of microgram quantities of protein utilizing the principle of protein-dye binding. Anal. Biochem. 72, 248-254.

Clairbone, A., 1985. Catalase activity. In: Greenwald, R.A. (Ed.), Handbook of Methods for Oxygen Radical Research. CRC Press, Boca Raton, pp. 283 284

Dodet, B., 1991. La chasse aux radicaux libres oxygénés. Biofutur, May 23-34.

Feirabend, J., Schaan, C., Hertwig, B., 1992. Photoinactivation of catalase occurs under both high and low temperature stress conditions and accompanies photoinactivation of photosystem II. Plant Physiol. 100, 1554-1556.

Foyer, C.H., Le Landais, M., Kunert, K.J., 1994. Photooxidative stress in plants. Physiol. Plant. 92, 696-717.

Foyer, C.H., Noctor, G., 2005. Redox homeostasis and antioxidant signalling: a metabolic interface between stress perception and physiological responses. Plant Cell 17, 1866-1875.

James, F.D., Inze, D., Van Brensegen, F., 2001. Catalase deficient tobacco plants: tools for in plant studies on the role of hydrogen peroxide. Redox Rep. 6, 37-42.

Laemmli, U.K., 1970. Cleavage of structural proteins during the assembly of the head of bacetriophage T4. Nature 227, 680-685.

Matsumura, T., Tabayashi, N., Kamagata, Y., Souma, C., Saruyama, H., 2002. Wheat catalase expressed in transgenic rice can improve tolerance against low temperatures stress. Physiol. Plant. 116, 317-327.

Murashige, T., Skoog, F., 1962. A revised medium for rapid growth and bioassays with tobacco cultures. Physiol. Plant. 15, 473-497.

Noel, S., 2001. Rôle du peroxyde d'hydrogène au cours de la dormance du tubercule de pomme de terre (Solanum tuberosum L.). Mémoire de fin d'études d'Ingénieur Agronome. Faculté Universitaire des Sciences Agronomiques de Gembloux, Belgium, $71 \mathrm{p}$.

Puntarol, S., Sanchez, R.A., Boveris, A., 1988. Hydrogen peroxide metabolism in soybean embryonic axes at the onset of germination. Plant Physiol. 86, 626-630.

Sairam, K.R., Veerabhadra Rao, K., Srivastava, G.C., 2002. Differential response of wheat genotypes to long term salinity stress in relation to oxidative stress, antioxidant activity and osmolyte concentration. Plant Sci. 163, 1037-1045.

Scandalios, J.G., 2002. The rise of ROS. Trends Biochem. Sci. 27, 483-486.

Shikanai, T., Takada, T., Yamauchi, H., Sano, S., Tomizawa, K., Yokota, A., Shigeoka, S., 1998. Inhibition of ascorbate peroxides under oxidative stress in tobacco having bacterial catalase in chloroplasts. FEBS Lett. 428, 47-51.

Vidalie, H., 1978. Comportement de différents cultivars de glaïeuls précoces cultivés sous tunnel. Pép. Hort. Mar. 192, 13-18.

Volk, S., Feirabend, J., 1989. Photoinactivation of catalase at low temperature and its relevance to photosynthetic and peroxide metabolism in leaves. Plant Cell. Env. 12, 701-712.

Wadsworth, G.L., Scandalios, J.G., 1990. Molecular characterization of a catalase null allele at cat3 locus in maize. Genetics 125, 867-872.

Warm, E., Laties, G.G., 1982. Quantification of hydrogen peroxide in plant extracts by chimioluminescence reaction with luminol. Phytochemistry 21 , $827-831$

Willekens, H., Langebartels, C., Tiré, C., Van montagu, M., Inzé, D., Van Camp, W., 1994. Differential expression of catalase genes in Nicotiana plumbaginifolia. Proc. Natl. Acad. Sci. U.S.A. 91, 10450-10454.

Willekens, H., Inzé, D., Van Montagu, M., Van Camp, W., 1995. Catalases in plants. Mol. Breed. 1, 207-228.

Willekens, H., Chamnogpol, S., Davey, M., Schravdner, M., Langebartels, C., Van Montagu, C., Inzé, D., Van Camp, W., 1997. Catalase is a sink for $\mathrm{H}_{2} \mathrm{O}_{2}$ and is indispensable for stress in $\mathrm{C}_{3}$ plants. EMBO J. 16, 4806-4816. 